\title{
Екологічна структура флори породних відвалів шахт Нововолинського гірничопромислового району
}

\section{Оксана Музиченко, Сергій Ліщук, Ольга Караїм}

Волинський національний університет імені Лесі Українки

Адреса для листування: muzychenko.oksana@vnu.edu.ua

Резюме. В роботі наведено аналіз екологічної структури флори породних відвалів Нововолинського гірничопромислового району (НГПР). Описано видовий склад флори породних відвалів НГПР. У флорі відвалів домінують представники класу Magnoliopsida. Провідними родинами флори породних відвалів шахт $є$ Asteraceae, Poaceae, Fabaceae та Brassicaceae. Флора вугільних відвалів шахт НГПР бідна на видовий склад, більшість родин мають низький рівень флористичного запасу (1-3 види). У флорі відвалів переважають мезофіти, мезотрофи та індиферентні види рослин за відношенням до сольового складу грунту. Характерний склад флори пов'язаний з морфологічними й мікрокліматичними умовами відвалів та біологічними особливостями рослин.

Ключові слова: Нововолинський гірничопромисловий район, породний відвал, флора, екологічна структура.

\section{Ecological structure of the flora of waste heaps of Novovolynsk mining district}

\section{Oksana Muzychenko, Serhii Lishchuk, Olha Karaim}

Lesya Ukrainka Volyn National University, Lutsk, Ukraine

Correspondence: muzychenko.oksana@vnu.edu.ua

\begin{abstract}
Analysis of the ecological structure of the flora of the waste heaps of the Novovolynsk mining district (NMD). The species composition of the flora waste heaps of NMD is described, which includes 49 species belonging to 45 genera, 17 families, 16 orders, 4 classes and 3 phyla. The Magnoliophyta division has 47 species $(95,91 \%)$. Magnoliopsida dominates in the number of species - 79,59\%, the share of Liliopsida is $16,33 \%$. The leading families of the flora of the mine waste heaps are Asteraceae $-26,32 \%$, Poaceae $-16,32 \%$, Fabaceae $-10,20 \%$ and Brassicaceae $-8,16 \%$. The most common are members of the family Asteraceae, which include 13 species or $26,53 \%$ of the total. The processes of natural overgrowing of dumps are actively taking place on the slopes and at the foot, more slowly - at the top.

Among the hygromorphs in the flora are the representatives of the mesophytes group (67,37\%), which mainly inhabit the foothills of the northern and western slopes. The presence of a significant number of mesophytes is due to the biological reclamation of waste heaps. In terms of substrate trophic, the most mesotrophic species $(63,27 \%)$ are explained by the biological recultivation of waste heaps. In terms of the salt composition of the soil, the flora is dominated by indifferent species $(40,81 \%)$. The flora of the coal mines of the NMD mines is poor in species composition, most families $(76,47 \%)$ have a low level of floristic stock (1-3 species). The flora of the dumps is dominated by mesophytes, mesotrophics and indifferent plant species in relation to the soil saline composition. The characteristic composition of the flora is associated with the morphological and microclimatic conditions of the dumps and the biological characteristics of the plants.
\end{abstract}

Key words: Novovolynsk mining district, waste heap, flora, ecological structure.

\section{ВСТУП}

Інтенсивне ведення господарської діяльності та нераціональне використання природних ресурсів веде до збільшення обсягів видобутку корисних копалин, що й призводить до негативних екологічних наслідків.

На сьогодні головною проблемою 
видобувної промисловості $є$ значне накопичення відвалів пустої породи й утворення кар'єрів, які займають великі території, порушують цілісність земної поверхні, унаслідок чого втрачаються значні площі родючих земель.

На території Нововолинського гірничопромислового району (НГПР) ЛьвівськоВолинського кам'яновугільного басейну розташовано 28 териконів вугільних шахт. Така кількість породних відвалів призводить до низки негативних змін у довкіллі, зокрема до забруднення поверхневих i підземних вод, підвищення радіаційного фону, забруднення атмосфери та грунтів, а особливо - до деградації природних ландшафтів [1].

Шахтні відвали формують типи ландшафтів, які відрізняються своїми, якісно новими, морфологічними та фітоценотичними умовами порівняно 3 зональними ландшафтами. Такий тип ландшафтів називають девастованим або зруйнованим.

Для екотопів териконів характерна певна специфічність по відношенню до механічного, фізико-хімічного складу висипних порід та мікрокліматичних умов. У мезорельєфі відвалів переважають круті схили, що зумовлюють зменшення кількості опадів на одиницю площі, верхні частини відвалів зазнають впливу високих швидкостей вітру та різкої зміни гідротермічного коефіцієнта, у нижніх частинах схилів відвалів відзначається наявність місцезростань із підвищеним локальним зволоженням у місцях невпорядкованих виїмок породи тощо, що визначає екологічну структуру фітоценозів цих територій [2].

Екологічні проблеми техногенно порушених територій розглядали у своїх роботах І. П. Ковальчук, Ю. О. Малик. У дослідженнях В. В. Поповича показано вплив кліматичних умов на розвиток рослинності техногенних ландшафтів Нововолинського гірничопромислового району. Флору шахтних відвалів Червоноградського гірничопромислового району вивчали У. Б. Башуцька, О. Т. Кузярін [3-4].

Дослідження Т. Є. Комісової, О. П. Губської та О. О. Кучер напрямів сукцесійних процесів на відвалах вугільних шахт міста Краснодона Луганської області встановило залежність між стадіями сукцесії та віком відвалів [14].

За останні роки видовий набір рослинних угруповань виробничих відвалів Нововолинського ГПР зазнав значних перетворень. Він досить збіднений на флористичне різноманіття, що є причиною жорстких та нетипових умов зростання [5]. Утворення рослинного покриву на шахтних відвалах проходить за зональним принципом 3 низькою швидкістю та інтенсивністю процесу заростання. Їх фітомеліорація ускладнена втраченим потенціалом родючості та несприятливими локальними кліматичногідрологічними умовами [6].

Найбільш ефективним способом покращення екологічного стану таких територій $\epsilon$ проведення фіторекультивації. Оптимізація відновних процесів на девастованих ландшафтах можлива за умови вироблення комплексу фітомеліоративних заходів на основі пізнання екологічних умов та особливостей формування рослинного покриву [7]. У зв'язку 3 цим актуальним $\epsilon$ дослідження процесів природного заростання та зміни видового флористичного різноманіття на териконах вугільних шахт, що в подальшому надасть можливість підвищити фітомеліо-ративну ефективність і відновлювальну здатність рослинного покриву порушених ландшафтів.

Метою нашої роботи $є$ аналіз екологічної структури флори шахтних відвалів Нововолинського гірничопромислового району.

\section{МАТЕРІАЛИ Й МЕТОДИ ДОСЛІДЖЕНЬ}

Дослідження флори Нововолинського ГПР проводили в 2018-19 рр. на териконах шахт №4 i №8 (рис. 1).

Відвали шахти № 4 знаходяться в північнозахідній частині м. Нововолинська, займають площу 7,4 га і мають висоту близько 30 м. Ці відвали пройшли усі етапи рекультивації. Формування терикону відбувалось у трапецієподібний спосіб, тому схили першого ярусу старіші, з чітко вираженими терасами й добре сформованим рослинним покривом. Процеси природного заростання відвалу нерівномірні. У підніжжя та на схилах ростуть дерева Robinia pseudoacacia (L.) 3 домішкою Betula pendula (Roth.) та Populus tremula (L.). У формуванні рослинного покриву верхніх плато відіграють трав' янисті рослини.

Відвали шахти №8 3 висотою понад $35 \mathrm{~m}$ розташовані на північний схід від міста, займають площу 2,3 га та частково рекультивовані.

Список видів рослин флори породних відвалів вугільних шахт м. Нововолинська складено на основі маршрутного методу та шляхом закладання тимчасових пробних ділянок розміром 10х10 м.

Визначення видів рослин проводили за визначниками та довідниками [8], систематичний аналіз флори здійснювали за 


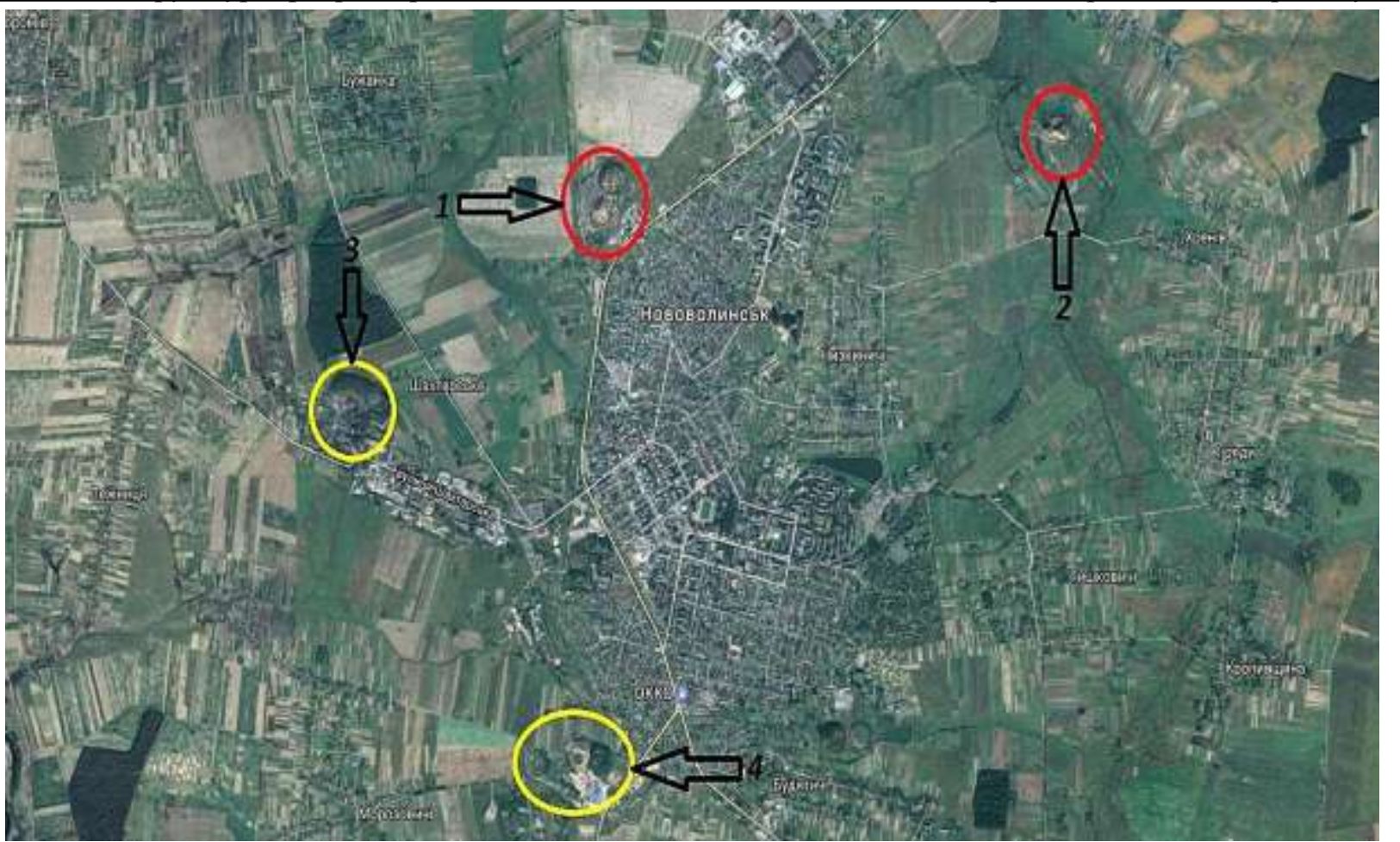

Рис. 1. Схема розміщення териконів м. Нововолинська (1 - шахти №4;

2 - шахти №8; 3 - шахти № 1; 4 - шахти №2)

(Фото зроблене за допомогою сервісу Google Maps)

А. Л. Тахтаджяном [9], номенклатуру подали за С. Л. Мосякіним 3 М. М. Федорончуком [11]. Екологічний аналіз флори здійснено за відношенням до водного режиму грунту, освітленості, вмісту у грунті елементів мінерального живлення та хімізму субстрату. Основні екоморфи судинних рослин ідентифіковано за сучасними літературними джерелами [10].

\section{РЕЗУЛЬТАТИ ТА ЇХ ОБГОВОРЕННЯ}

Нововолинський гірничопромисловий район розташований в південно-західній частині Волинської області. Всі шахти вуглевидобувного району розміщені в межах Іваничівського району та входять до складу ДП «Волиньвугілля». А вже разом із Червоноградським та Північно-Західним ГПР Нововолинський ГПР входить до ЛьвівськоВолинського кам'яновугільного басейну.

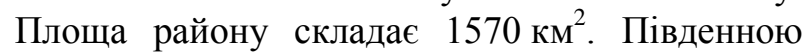
межею району виступає адміністративний кордон Волинської та Львівської областей, північною та західною - річка Західний Буг, східною - контур виходу вапняку [12].

За фізико-географічним розташуванням територія району належить до Малого Полісся. Клімат досліджуваної території помірноконтинентальний, який характеризується значними обсягами опадів, відносно високим ступенем вологості та мінливими погодними умовами.

Домінуючими типами грунтів $\epsilon$ сірі опідзолені, темно-сірі та ясно-сірі, які поширені на найвищих частинах вододільних плато й утворені на лесоподібних суглинках. На сьогодні грунти Нововолинського ГПР досить трансформовані через гірничодобувну діяльність. Значні площі потенційно-родючих грунтів вилучені із сільськогосподарського обігу під потреби гірничодобувних підприємств і потребують рекультивації та фітомеліорації [13].

До флори шахтних відвалів відносимо сукупність популяцій усіх видів, які поселяються природним шляхом, а також ті, що штучно створені людиною. Для кожного 3 досліджуваних відвалів характерна різна кількість видів. Наприклад, на відвалах шахти №4 виявлено 46 видів, а на відвалах шахти №8 - 43 види рослин. Загалом було описано 49 видів флори, які належать до 45 родів, 17 родин, 16 порядків, 4 класів і 3 відділів (табл. 1).

До відділу Pinophyta належить один вид Pinus sylvestris (L.). Є Сииним представником родини Polytrichaceae $€$ мох Polytrichum commune (Hedw). Тут він відіграє середови- 
Систематичний склад флори породних відвалів шахт №4 та №8 м. Нововолинська

\begin{tabular}{|c|c|c|c|c|c|}
\hline \multirow{2}{*}{ Відділ } & \multirow{2}{*}{ Клас } & \multicolumn{4}{|c|}{ Кількість } \\
\cline { 2 - 6 } & & порядків & родин & родів & видів \\
\hline Bryophyta & Polytrichopsida & 1 & 1 & 1 & 1 \\
\hline Pinophyta & Pinopsida & 1 & 1 & 1 & 1 \\
\hline \multirow{2}{*}{ Magnoliophyta } & Magnoliopsida & 13 & 14 & 3 & 39 \\
\cline { 2 - 7 } & Liliopsida & 1 & 1 & $\mathbf{4}$ & 8 \\
\hline Всього & $\mathbf{4}$ & $\mathbf{1 6}$ & $\mathbf{4 5}$ & $\mathbf{4 9}$ \\
\hline
\end{tabular}

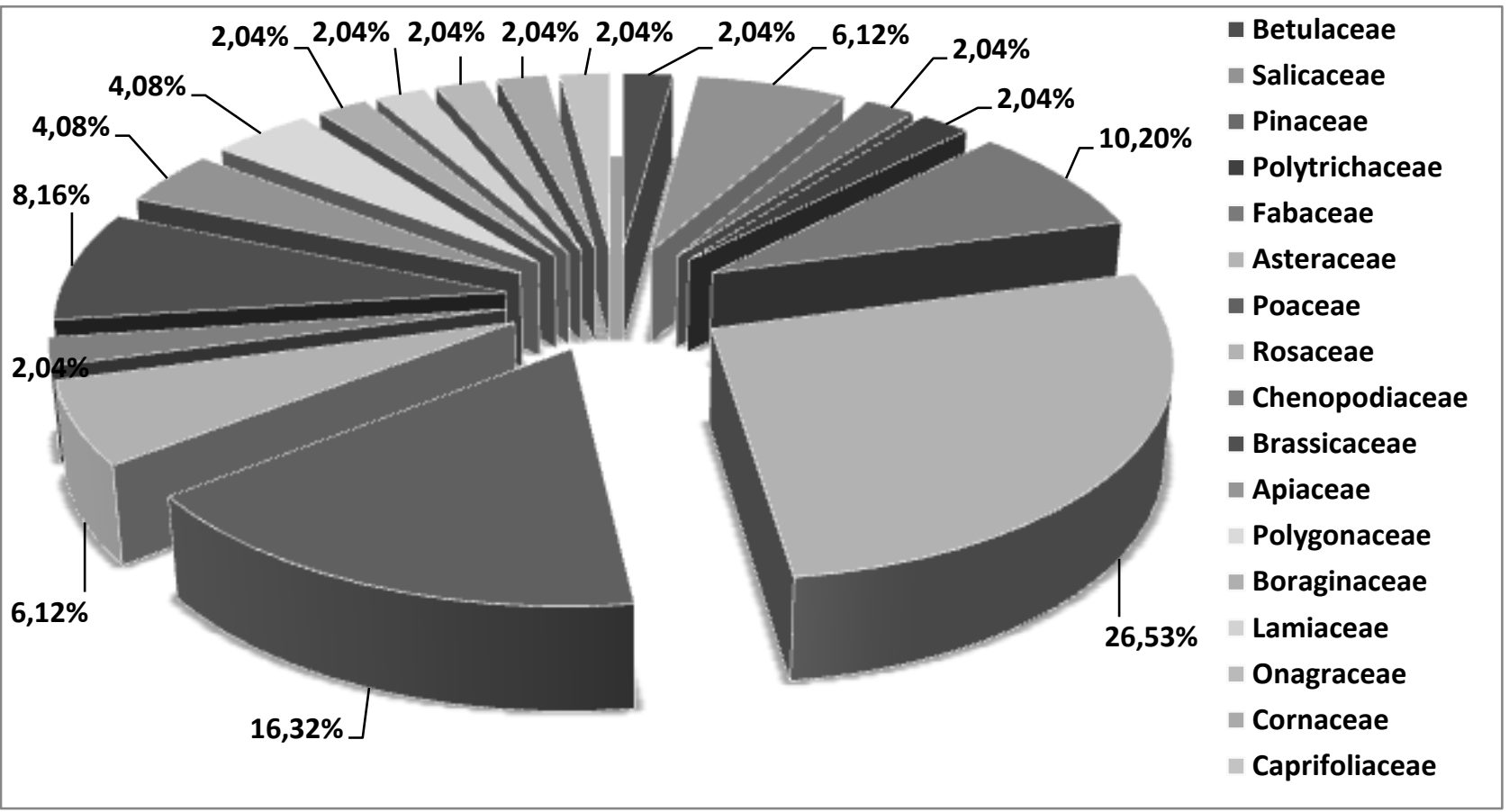

Рис. 2. Провідні родини флори породних відвалів шахт №4 та №8 м. Нововолинська

щетвірну роль, що й засвідчує проходження первинної сукцесії на породних відвалах [14]. Відділ Magnoliophyta налічує 47 видів. За кількістю видів домінує Magnoliopsida $79,59 \%$, частка Liliopsida становить $16,33 \%$.

Провідними родинами флори породних відвалів шахт №4 і №8 є: Asteraceae - 26,32\%, Poaceae - 16,32\%, Fabaceae - 10,20\% та Brassicaceae $-8,16 \%$ (рис. 2).

Більшість родин (13) мають низький рівень флористичного запасу (1-3 види) та налічують 19 видів, тобто 38,78\% від загальної кількості. Найбільш поширені представники родини Asteraceae, яка об'єднує 13 видів або 26,53\% від загальної кількості, ці види входять до рослинного покриву усіх мезоформ рельєфу шахтних відвалів.

Екологічна структура флори виражає розподіл видів на різні екологічні групи за відношенням до умов середовища й відповідної реакції на них рослинних організмів. Для екотопів шахтних відвалів характерна специфічність за відношенням до механічного, фізико-хімічного складу висипних порід та мікрокліматичних умов.

У мезорельєфі відвалів переважають круті схили, що призводить до зменшення кількості опадів на одиницю площі, верхні частини відвалів зазнають впливу високих швидкостей вітру та різкої зміни гідротермічного коефіцієнта. У нижніх частинах схилів відвалів відзначається наявність місцезростань із підвищеним локальним зволоженням у місцях невпорядкованих виїмок породи тощо, що зумовлює особливості в екологічній структурі фітоценозів цих територій [15].

За відношенням до зволоження виділили 3 групи та 4 підгрупи рослин (рис. 3). Гідрофільна група об'єднує гідрофіти та гігромезофіти. До іiі складу входить 5 видів $(10,22 \%)$, серед них поширені породи. Deschampsia caespitosa(L.) Beauv.), Festuca pratensis (Huds.) i Tussilago farfara(L.), які заселяють переважно підніжжя північних та 


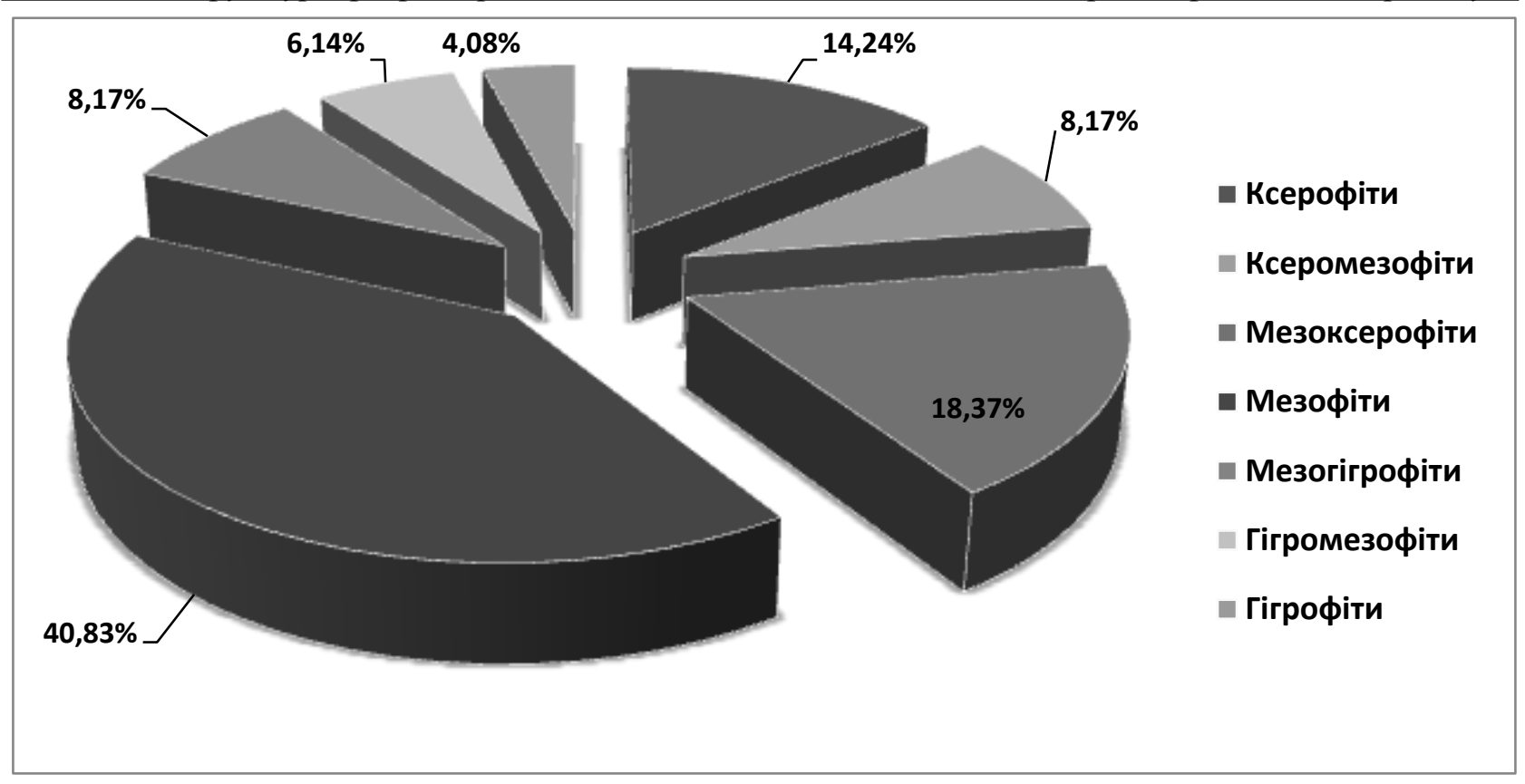

Рис. 3. Структура флори породних відвалів шахт №4 та №8 відносно зволоження

західних схилів, а також подекуди поширені на вершині рекультивованого терикону шахти №4 у затінених та надмірно зволожених мікропониженнях і виїмках рекультивованих терас. Присутність таких гігрофітів, як Phragmites australis (Cav.) Trin. ex Steudel.) i Salix fragilis (L.) зумовлена наявністю заболочених територій та невпорядкованих виїмок

Мезофільна група, яка налічує 33 види (67,37\%), складається 3 мезоксерофітів, мезофітів і мезогігрофітів та є найчисельнішою серед видового складу рослинного покриву відвалів. Вона переважає на всіх досліджуваних відвалах. Мезофіти та рідше мезоксерофіти заселяють здебільшого бічні поверхні териконів та нижні частини схилів. Зокрема, на західних та північних експозиціях відвалів розвивається мезофіт B. pendula (Roth), а в нижніх частинах схилів утворюються угруповання мезогігрофіта $P$. tremula (L.).

Це пояснюється доброю зволоженістю субстрату й акумулюванням вологи у нижніх шарах відвалів. Такі види як Salix caprea (L.), Rubus caesius (L.), Daucus carot (L.), Achillea millefolium (L.), Chamerion angustifolium (L.) Holub), Taraxacum officinale (Wigg.), Swida sanguinea (L.) Fourr.) та інші беруть активну участь у процесах природного заростання відвалів i мають яскраво виражений мезофільний характер, притаманний флорі Малого Полісся.

До ксерофільної групи, яка включає ксерофіти та ксеромезофіти, належить 11 видів
(22,41\%). Представники цієї групи переважно зростають на схилах південної та східної експозиції, а також верхніх плато. Такі види як Hieracium pilosella(L.), Artemisia absinthiu (L.), Pimpinella saxifraga (L.) та Pinus sylvestris (L.) - піонери на ділянках самозаростання. Одним iз найпоширеніших ксерофітів на рекультивованих відвалах $€$ R. Pseudoacacia (L.), яка має досить високі прирости та утворює суцільний деревний покрив.

Відносно трофності субстрату у флорі виділено групи оліго-, мезо- та мегатрофних рослин (рис. 4). До групи оліготрофів належить 12 видів (24,48\%), які поселяються спонтанно та невибагливі до родючості грунтів. Серед дерев до оліготрофів належать B. pendula (Roth), P. tremula (L.) та R. Pseudoacacia (L.). Серед трав'яних рослин це Calamagrostis epigeios L.) Roth.), H. Pilosella(L.), Artemisia vulgaris (L.) тощо.

Більшу частину загального видового складу рослинного покриву досліджуваних відвалів займає група мезотрофних видів, до якої належить 31 вид $(63,27 \%)$. Присутність значної кількості мезофітів зумовлена проведенням біологічної рекультивації породних відвалів. У видовому спектрі переважають трав'янисті рослини, а саме: Fragaria vesca (L.), Trifolium repens (L.), Barbarea vulgaris (W.T.Aiton), Arctium minus (Hill) Bernh.) тощо. 3 деревночагарникових порід основними є Swida sanguinea (L.) Opiz), Sambucus nigra (L.), Rosa canina (L.). 


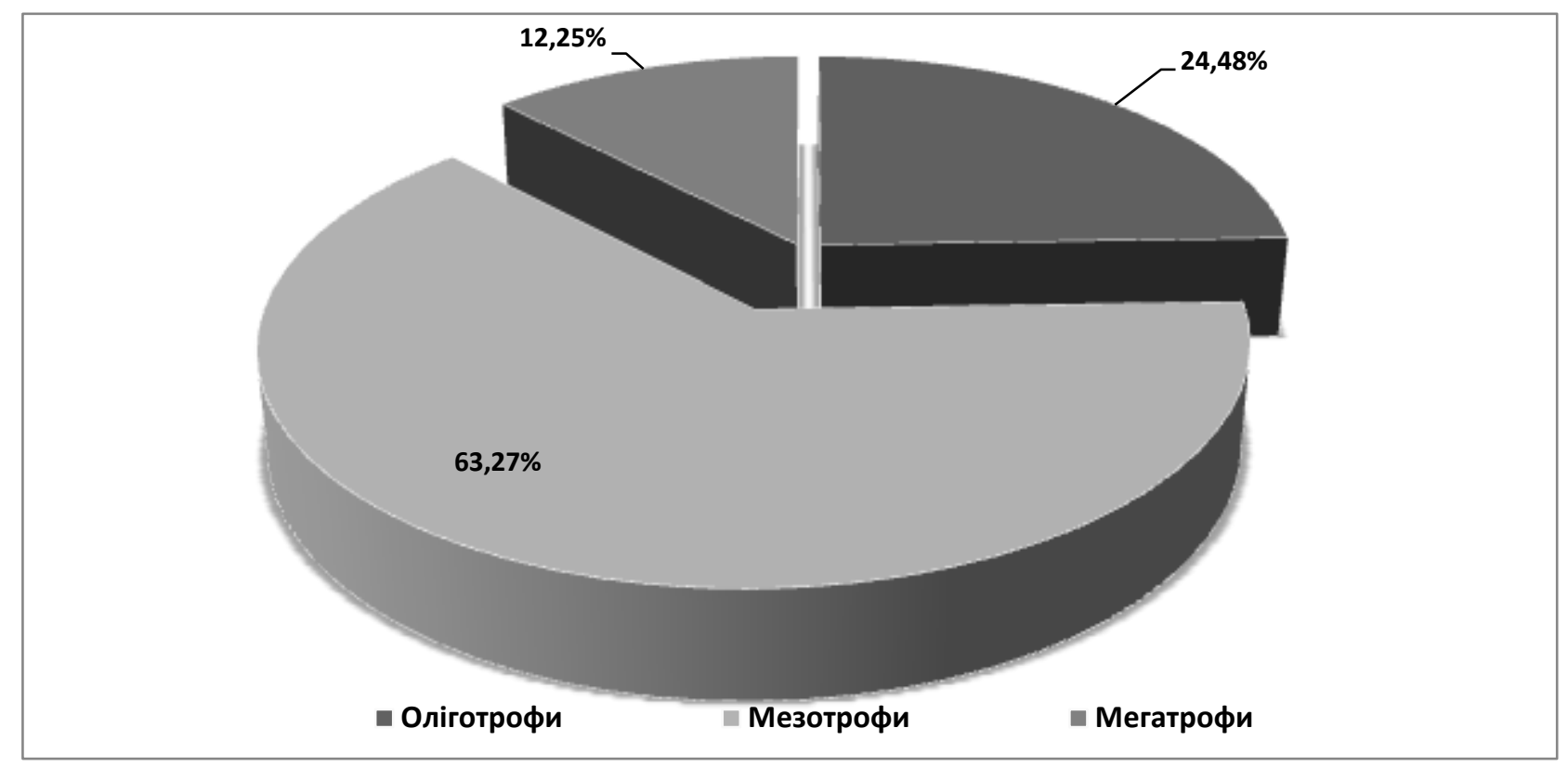

Рис. 4. Структура флори породних відвалів шахт №4 та №8 відносно трофності субстрату

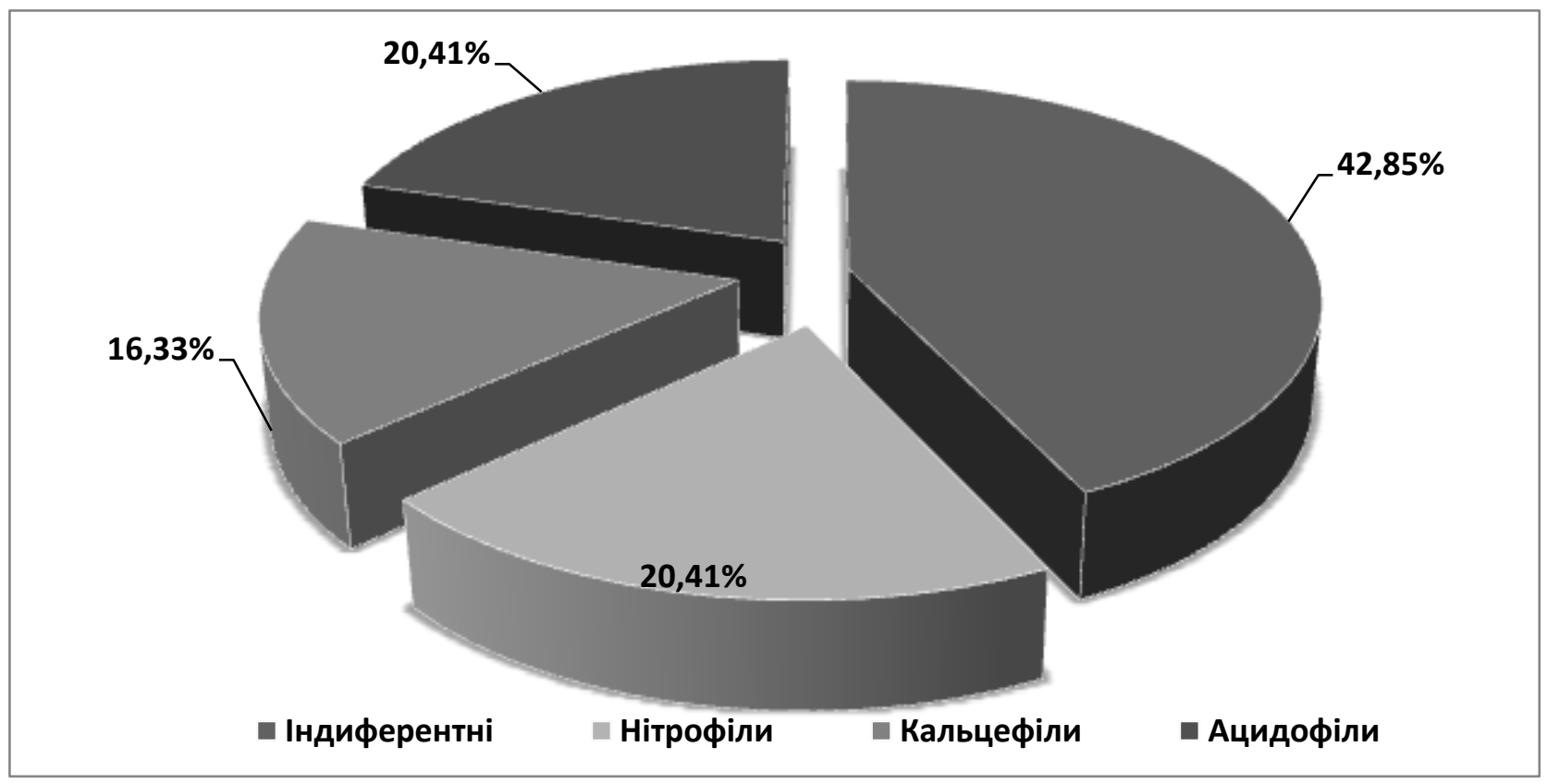

Рис. 5. Структура флори породних відвалів шахт №4 та №8 відносно хімізму субстрату

Види мегатрофної групи трапляються здебільшого на заболочених ділянках, у підніжжях та частково на рекультивованих терасах відвалів і налічують 6 видів (12,25\%). Для заболочених ділянок притаманні P. Australis (Cav.) Trin. ex Steud.), S. Fragilis (L.), D. Caespitosa (L.) Beauv.). На рекультивованих терасах зростають Symphytum officinale (L)., Poa pratensis (L.) та Poa trivialis (L.).

Крім вологості та родючості грунту, на видовий склад рослин відвалів впливає сольовий склад субстрату. Залежно від реакції на хімізм субстрату досліджували індиферентні види, нітрофіли, кальцефіли й ацидофіли (рис. 5). Група індиферентних видів 3 широкою екологічною амплітудою відносно хімізму субстрату складає 21 вид (40,81\%). Рослини трапляються на усіх формах мезорельєфу: Cirsium arvense (L.) Scop.), Chenopodium glaucum (L.), Carduus acanthoides (L.), на заболочених ділянках P. australis (Cav.) Trin. ex Steud.), D. caespitosa (L.) Beauv.) тощо.

Види нітрофільної групи, які зростають на грунтах 3 високим вмістом сполук нітрогену, складають 10 видів $(20,41 \%)$ (рис. 5). В основному це синантропна та лучна рослинність відвалів, серед яких є H. pilosella (L.), D. carota (L.), Rumex confertus (L.), 
Екологічна структура флори породних відвалів шахт Нововолинського гірничопромислового району

Polygonum aviculare (L.), Trifolium repens (L.) тощо.

Група кальцефілів нараховує 8 видів або 16,33\%. Вони поширені на всіх досліджуваних відвалах та мають значне проективне покриття, це - R. pseudoacacia (L.), Lotus arvensis (Pers), Dactylis glomerata (L.), P. trivialis (L.).

Група ацидофілів, або рослини закислених грунтів, включає 10 видів (20,41\%). До цієі групи належать дерева $B$.pendula (Roth.),

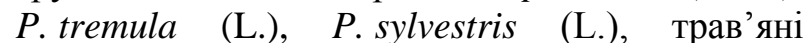
рослини C. epigeios (L.) Roth.), A. absinthium (L.), P.pratensis (L.), які $€$ піонерами заростання, широко освоюють породні субстрати та створюють умови для розвитку інших видів рослин [16].

\section{ВИСНОВКИ}

Екологічна структура флори породних відвалів нерівномірна. В екологічному спектрі стосовно зволоження субстрату переважають види мезофітної групи, стосовно трофності субстрату - мезотрофи. Значну роль у процесах природного заростання відіграють представники оліготрофів, які заселяють схили та вершини відвалів.

Найчисленнішою групою відносно хімізму субстрату $\epsilon$ індиференти, які представляють видовий набір типовий для рекультивованих відвалів. Друге місце розділяють нітрофіли, які представлені синантропною й лучною рослинністю, та ацидофіли - види-піонери, які відіграють важливу роль у формуванні життєвого середовища для інших видів рослин. Група кальцефілів має найменший флористичний запас та складається 3 видів лучної й лісової флори, що сприяє формуванню зонального типу рослинного покриву.

Поширення та проективне покриття вищевказаними видами зумовлено морфологічними й мікрокліматичними умовами відвалів та біологічними особливостями рослин. Більш детальне вивчення екологічної структури рослинного покриву цих територій дасть змогу в подальшому провести комплексні та раціональні фітомеліоративні заходи задля оптимізації екологічної ситуації техногенно порушених ландшафтів.

\section{ЛITEPАТУРА}

1. Попович, В. В. Фітомеліорачія згасаючих териконів Львівсько-Волинського вугільного басейну. ЛДУ БЖД: Львів, 2014, 174 с.

2. Жуков, С. П. Диференціація екологічних ніш видів та формування фітоценозів на техногенно порушених землях. Промислова ботаніка: зб. навч. $n p$. Донецьк: Донецький ботанічний сад НАН України. Вип. 11. 2011, с 36-41.

3. Башуцька, У.Б. Сукиесї рослинності породних відвалів шахт Червоноградського гірничопромислового району. РВВ НЛТУ України: Львів, 2006, 180 с.

4. Кузярін, О. Т. Анотований список судинних рослин вугільних відвалів Львівсько-Волинського гірничопромислового регіону. Біологічні студї / Studia Biologica. 2010, 5 (3). C 155-170.

5. Іванов, С.А. Формування рослинного покриву породних відвалів шахт ЛьвівськоВолинського вугільного басейну. Актуальные научные исследования в современном мире: матер. VI-ой Междунар. научн.-практ. интернет-конф. (26-27 октября 2015 г.). Переяслав-Хмельницкий. Вып. 6. 2. 2015, с 130-134.

6. Макеєва, Д. О. Екологічна небезпека породних відвалів та шляхи вирішення проблеми. Проблеми екології. 1 (31). 2013, с 43-48.

7. Піндер, В. Ф.; Попович, В. В. Рекультивація породних відвалів ліквідованих шахт ЛьвівськоВолинського вугільного басейну. Науковий вісник НЛТУ України. 27 (3). 2017, с 113-116.

8. Определитель высших растений Украины / Доброчаева Д. Н., Котов М. И., Прокудин Ю. Н. и др. Наукова думка: Киев, 1987, 548 с.

9. Тахтаджян, А. Л. Система магнолиофитов. Наука: Ленинград, 1987, 439 с.

10. Дідух, Я. П.; Плюта, П. Г.; Протопопова, В. В. та ін. Екофлора Украӥни. Фітосоціоцентр: Київ, 2000, 284 c.

11. Mosyakin, S. L.; Fedoronchuk, M. M. Vascular plants of Ukraine. A nomenclatur cheklist. M. G. Kholodny Institute of Botany: Kiev, 1999, 760 p.

12. Іванов, Є. Еколого-геодинамічні ризики гірничодобувної діяльності у межах процесонебезпечних територій. Національна безпека Украӥни у викликах новітньої історії / уклад. В. І. Шпак; кер. ав. кол. С. І. Табачніков. Експресоб'ява: Київ, 2020, с 109-124.

13. Бузило, В. І.; Павличенко, А. В. Екологічні та техногенні наслідки ліквідації вугільних шахт. Розробка родовищ:: щзорічний науково-технічний збірник. ТОВ Лізунов Прес Дніпропетровськ, 2014, c 535-540.

14. Комісова, Т. С.; Губська, О. П.; Кучер, О. О. Напрямок сукцесійних процесів на територіях відвалів вугільних шахт м. Краснодона Луганської області. Людина та довкілля. Проблеми неоекології. 1-2 (21). 2014, с 92-97.

15. Неспляк, О. С. Сукцесії рослинного покриву золошлаковідвалів Бурштинської ТЕС. Вісник Прикарпатського університету, серія Біологія. Вип. XIV. 2009, с 84-88.

16. Бешлей, С. В.; Баранов, В. І.; Микієвич, I. M. Зміна субстратів відвалів породи Червоноградського гірничопромислового району при заростанні куничником наземним (Calamagrostis epigeios (L.) Roth). Біологічні студіi. 4 (2). 2010, c 75-82. 